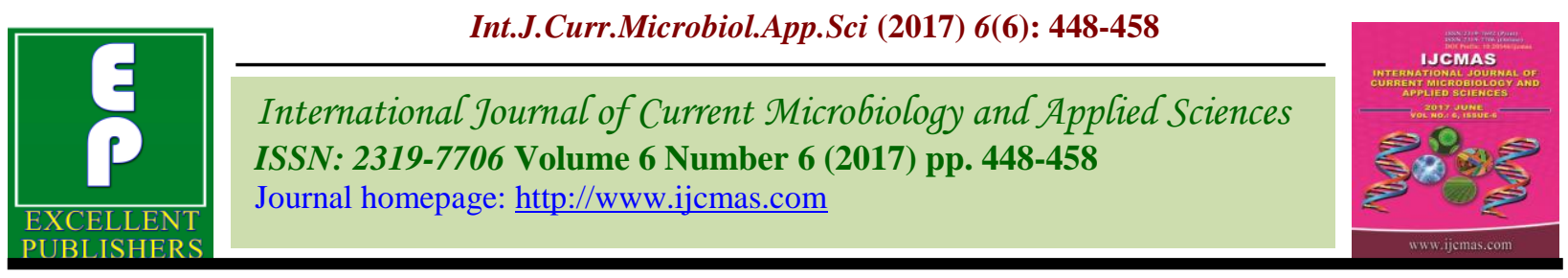

Original Research Article

https://doi.org/10.20546/ijcmas.2017.606.052

\title{
Use of Rice Husk Ash to Lower the Sodium Adsorption Ratio of Saline Water
}

\author{
Parminder Singh, Sunil Garg*, Sanjay Satpute and Angrej Singh
}

Dept. of Soil and Water Engineering, PAU, Ludhiana-141004, India

*Corresponding author

\section{A B S T R A C T}

Keywords

Rice husk ash,

Coco peat,

Adsorption,

Activated charcoal,

Batch method.

Article Info

Accepted:

04 May 2017

Available Online:

10 June 2017

Laboratory studies were performed for selection of effective adsorbent from various adsorbents based on two methods of adsorption i.e. column method and batch method. Column method was found to be better adsorption technique than batch method to achieve desalination as its $\mathrm{Na}+$ adsorption capacity was more and rice husk ash (RHA) was proved to be the best adsorbent. Rice husk ash has higher percentage of sodium chloride adsorption of $27.83 \%$, followed by rice straw biochar $(25.52 \%)$, activated charcoal $(22.21 \%)$ and coco peat $(15.46 \%)$. Rice husk ash reduced sodium adsorption ratio is from 18.75 to 8.84 below permissible limit (18). Optimum contact time for all adsorbents was found out to be 15 minutes.

\section{Introduction}

Groundwater is the major source of freshwater that caters to the demand of ever growing domestic, agricultural and industrial sectors which have put a severe pressure on the available resources and have adversely impacted in the form of long-term decline of groundwater levels (Rodell et al., 2009). In some areas the groundwater has high salt content in the form of dissolved cations and anions, which affect its suitability for irrigation. So, all the available water is not of good quality. Significant part of the groundwater surveyed in the many states of India has rated either saline or alkali (Minhas, 1996). The problem of the poor quality of irrigation water is also encountered in many areas of Punjab. Poor quality waters, without proper management and careful regard to their overall salinity and ionic composition pose risks to soil conditions and the environment (Jha, 2016). A feature common to most of poor quality water is an increase in their sodium content in relation to calcium and magnesium ions, defined in terms of sodium adsorption ratio (SAR) (Singh et al., 1992). High value of SAR of water results in decreased hydraulic conductivity, decreased aggregate stability, clay dispersion, swelling of expandable clays, surface crusting and reduced tilth (Suarez et al., 2006). Elevated value of SAR along with soil salinity causes reduction of crop yields due to toxic and osmotic effects (Al-Hamaiedeh and Bino, 2010). There is increasing demand to reduce the high SAR value to permissible limits so that this water can be used for irrigation purposes. From agricultural point of view, there is a need of inexpensive and simple 
technique to reduce the level of SAR of water. So, finding efficient and inexpensive materials to develop technique is an important issue. So, the present study was undertaken for selection of suitable adsorbent to lower sodium adsorption ratio (SAR) of saline water.

\section{Materials and Methods}

\section{Selection of Adsorbent}

Adsorbent is material that has the ability to extract certain substances from gases, liquids, or solids by causing them to adhere to its surface. Adsorbents used in present study were selected after reviewing the literature on adsorbents which were proved to be capable of improving water quality in studies by different researchers. Selected adsorbents had undergone different adsorption studies in lab for the purpose of selection of most suitable adsorbent. Adsorbent used in studies were:

\section{Rice straw biochar (RSB)}

Rice straw biochar (RSB) is the porous and carbonaceous material obtained from thermo chemical treatment of organic materials in an oxygen-limited conditions (Crombie et al., 2013). Biochar has emerged as a capable biomaterial for pollutant adsorption from waste waters (Kizito et al., 2015). Biochar was converted into $4-8 \mathrm{~mm}$ in size as shown in figure 1a.

\section{Coco peat (CP)}

Cocopeat is the pithy material left when fibre is extracted from coconut husk (Shakeri et al., 2012). For present study, Coco peat was obtained in compact form which was loosen by dipping in water. Then it was dried and sieved to get size of $1-2 \mathrm{~mm}$ as shown in figure $1 b$.

\section{Rice husk (RH)}

Rice husk is obtained from milling of paddy; around $23 \%$ of the paddy weight is received as husk (Scaglioni and Badiale-Furlong, 2016). Recently, researchers have taken interest in the application and investigation of rice husk as an adsorbent (Zhang et al., 2014). Rice husk for present study is shown in figure 1c.

\section{Rice husk ash (RHA)}

Rice-husk ash is received after burning of rice husk. Many researchers reported rice husk ash (RHA) as a cheap adsorbent (Ahmaruzzaman and Gupta, 2011). Rice husk ash for present study was prepared by burning rice husk. View rice husk ash is as shown in figure 1d.

\section{Activated carbon (AC)}

Activated carbons are very effective adsorbents due to their large surface area, highly developed porosity, variable characteristics of surface chemistry, and high degree of surface reactivity (Dias et al., 2007). Activated carbon is prepared by chemical and physical activation of a carbonaceous material (Sudaryanto et al., 2006). Activated charcoal was in granular form having size 3-4 $\mathrm{mm}$ as shown in figure 1 e.

\section{Zeolites (ZL)}

Zeolites are microporous crystalline hydrated aluminosilicates of alkine and alkaline-earth metals, characterized by three dimensional frameworks of aluminosilicate tetrahedral (Apreutesei et al., 2008). Natural zeolite has been explored as successful adsorbent in the past years (Wang et al., 2008). Zeolite for present study was in powder form having size less than $0.2 \mathrm{~mm}$ as shown in figure $1 \mathrm{f}$. 


\section{Water quality criteria}

The following parameters were considered for developing water quality criteria for irrigation water and used to evaluate adsorption.

\section{Sodium chloride $(\mathrm{NaCl})$ concentration}

Sodium chloride $(\mathrm{NaCl})$ salt concentration was considered as total salt concentration of simulated saline water and observed in throughout the experiments for evaluating adsorption by adsorbent material in conducted study. The presence of $\mathrm{NaCl}$ in the irrigation water or in soil alters the nutritional balance of plants and can inhibit the growth and yields of various crops.

\section{Sodium adsorption ratio (SAR)}

Sodium adsorption ratio (SAR) parameter is used to determine the sodium hazard. In the irrigation water, this parameter indicates the amount of sodium, in relation to calcium and magnesium. SAR is determined by following equation.

$$
\mathrm{SAR}=\frac{\mathrm{Na}^{+}}{\sqrt{\frac{\mathrm{Ca}^{2+}+\mathrm{Mg}^{2+}}{2}}}
$$

\section{Residual sodium carbonate (RSC)}

The quantity of bicarbonate and carbonate in excess of calcium and magnesium impact the suitability of water for irrigation use. When the sum of carbonates and bicarbonates is more than sum of calcium and magnesium, there is chance of complete precipitation of calcium and magnesium. Residual sodium carbonate (RSC) is calculated to quantify the effects of carbonate and bicarbonate by following equation.

$$
\mathrm{RSC}=\left(\mathrm{CO}_{3}{ }^{2-}+\mathrm{HCO}_{3}{ }^{-}\right)-\left(\mathrm{Ca}_{2}{ }^{+}+\mathrm{Mg}_{2}{ }^{+}\right)
$$

\section{Laboratory tests to determine different ion concentration in water sample}

Lab tests were performed to find out ion concentration of sodium by flame photometry, magnesium and calcium ions by versenate method, chloride ions, carbonate and bicarbonate ions by Mohar's titration method for calculation of total $\mathrm{NaCl}$ content, SAR and RSC value of water sample.

\section{Aquifer saline water (ASW)}

Aquifer saline water (ASW) was collected from PAU Regional Research Station, Bathinda. Analysis was carried out on obtained aquifer water to determine concentration of different ions present in it. Analyzed data revealed the poor water quality of water and the results are given in table 1.

Based upon above determined ion concentrations in water, water quality parameter SAR and RSC were determined which are listed in table 2.

\section{Adsorption technique}

Adsorption is a surface phenomenon of increase in concentration of a particular component at the surface of adsorbent. Component that adheres to the surface is called an adsorbate. Adsorption process can be carried out by batch adsorption or column adsorption technique.

\section{Column adsorption studies}

Column adsorption studies were conducted using a glass column of $4 \mathrm{~cm}$ diameter and 40 $\mathrm{cm}$ height having a tap outlet at lower end. Glass wool was provided at the bottom of the glass column to check any movement of adsorbent particles through tap outlet. Adsorbent was filled in the glass column upto $20 \mathrm{~cm}$ height in every column adsorption test. 
Saline water was fed to the column through funnel upto adsorbent level with tap in closed state. Saline water in column was kept in contact with adsorbent for allotted contact time. The tap was opened and treated water was collected from tap outlet and filtered through Whatman filter paper and sealed in bottles for quality analysis. All experiments were carried out under room temperature. A view of the experimental setup used for column studies is shown in figure 2 .

\section{Batch adsorption studies}

In batch experiments, adsorption was performed on an orbital shaker as shown in figure 3. Five grams of adsorbent with $100 \mathrm{ml}$ of saline water was poured in $250 \mathrm{ml}$ Erlenmeyer flask and agitated on orbital shaker at $60 \mathrm{rpm}$ for allotted time. Then treated water was filtered through Whatman filter paper and sealed in bottles for quality analysis.

\section{Results and Discussion}

\section{Preliminary laboratory adsorption studies}

Initially, two types of adsorption methods and six selected adsorbent were used to carry out the adsorption study and results were compared to select better method and adsorbents for usage in further detailed adsorption studies.

\section{Adsorption by batch method}

Five grams of each six adsorbents was mixed with $100 \mathrm{ml}$ saline water in six different Erlenmeyer flasks and rotated in orbital shaker at $60 \mathrm{rpm}$ for 30 minutes. After shaking, treated water from each flask was filtered through Whatman filter paper and was tested for $\mathrm{Na}+$ concentration present in each sample. Results of adsorption are shown in table 3 .
Results enlisted in table 3 reveal adsorption capacity of adsorbents in following order: Rice husk ash > Coco peat > Rice straw biochar > Activated charcoal > Rice husk > Zeolite.

\section{Adsorption by column method}

Each adsorbent was filled in glass column up to $20 \mathrm{~cm}$ height. Saline water was filled in column up to adsorbent height and kept in contact with adsorbent for arbitrary time of 30 minutes. Treated water was filtered through Whatman filter paper and was tested for $\mathrm{Na}+$ concentration present in each sample. Results of adsorption are shown in table 4 .

Results enlisted in table 4 shows adsorption capacity of adsorbents in following order: Rice husk ash > Activated charcoal > Rice straw biochar > Coco peat > Rice husk > Zeolite. In case of zeolite, increase in $\mathrm{Na}+$ concentration was probably due to use of $\mathrm{Na}+$ enriched zeolite instead of $\mathrm{Ca} 2+$ enriched zeolite (Ganjegunte et al., 2011).

\section{Selection of adsorbents and adsorption} method for detailed adsorption studies

Results of adsorption by six adsorbents using batch method and column method are compared for selection of adsorption method and adsorbents for detailed adsorption studies. From figure 4 it was clear that column method showed better adsorption results for coco peat, rice husk ash, activated charcoal and rice straw biochar. So column method and above mentioned adsorbents were selected for further adsorption studies.

\section{Detailed laboratory adsorption studies}

After selection of column method for adsorption and four adsorbents, detailed laboratory study was carried out for further analysis. 
Table.1 Water quality analysis of ASW from PAU Regional Research Station, Bathinda

\begin{tabular}{|c|c|}
\hline Ion present & Value (me/l) \\
\hline $\mathrm{Na}^{+}$ & 37.5 \\
\hline $\mathrm{Cl}^{-}$ & 13.2 \\
\hline $\mathrm{Ca}^{2+}+\mathrm{Mg}^{2+}$ & 8.2 \\
\hline $\mathrm{Ca}^{2+}$ & 6.4 \\
\hline $\mathrm{CO}_{3}{ }^{2-}$ & 2.4 \\
\hline $\mathrm{HCO}_{3}{ }^{-}$ & 6.8 \\
\hline
\end{tabular}

Table.2 Water quality parameters of ASW from PAU Regional Research Station, Bathinda

\begin{tabular}{|c|c|c|}
\hline Parameter & Value & $\begin{array}{c}\text { *Permissible limit for } \\
\text { irrigation water }\end{array}$ \\
\hline SAR & 18.75 & 18 \\
\hline RSC $(\mathrm{me} / \mathrm{l})$ & 1.2 & 3 \\
\hline
\end{tabular}

*Permissible limits are taken from IS 11624-1986 (Reaffirmed 2009)

Table.3 Percentage adsorption of $\mathrm{Na}^{+}$by different adsorbents using batch method

\begin{tabular}{|c|c|c|c|c|}
\hline $\begin{array}{c}\text { S. } \\
\text { No }\end{array}$ & Adsorbent & $\begin{array}{c}\text { Initial Na } \\
\text { concentration (me/l) }\end{array}$ & $\begin{array}{c}\text { Final Na } \\
\text { concentration (me/l) }\end{array}$ & $\begin{array}{c}\mathbf{N a}^{+} \text {adsorption } \\
\text { (Percent) }\end{array}$ \\
\hline 1 & RSB & 37.5 & 28.21 & 9.29 \\
\hline 2 & RH & 37.5 & 33.93 & 3.57 \\
\hline 3 & RHA & 37.5 & 25.83 & 11.67 \\
\hline 4 & AC & 37.5 & 28.93 & 8.57 \\
\hline 5 & CP & 37.5 & 27.74 & 9.76 \\
\hline 6 & ZL & 37.5 & 52.98 & -15.48 \\
\hline
\end{tabular}

Table.4 Percentage adsorption of $\mathrm{Na}^{+}$by different adsorbents using column method

\begin{tabular}{|c|c|c|c|c|}
\hline $\begin{array}{c}\text { S. } \\
\text { No }\end{array}$ & Material & $\begin{array}{c}\text { Initial Na } \\
\text { concentration (me/l) }\end{array}$ & $\begin{array}{c}\text { Final Na } \\
\text { concentration (me/l) }\end{array}$ & $\begin{array}{c}\mathbf{N a}^{+} \text {adsorption } \\
\text { (Percent) }\end{array}$ \\
\hline 1 & RSB & 37.5 & 21.40 & 42.93 \\
\hline 2 & RH & 37.5 & 32.14 & 14.29 \\
\hline 3 & RHA & 37.5 & 17.30 & 53.87 \\
\hline 4 & AC & 37.5 & 20.10 & 46.4 \\
\hline 5 & CP & 37.5 & 25.43 & 32.19 \\
\hline 6 & ZL & 37.5 & 45.50 & -21.33 \\
\hline
\end{tabular}


Table.5 Ion concentration of aquifer saline water after adsorption by Single and combined adsorbents

\begin{tabular}{|c|c|c|c|c|c|c|c|c|c|}
\hline \multirow{3}{*}{$\begin{array}{c}\text { S. } \\
\text { No } \\
\text {. }\end{array}$} & \multirow{3}{*}{ Adsorbent } & \multicolumn{8}{|c|}{ Ion concentration (me/l) } \\
\hline & & \multicolumn{2}{|c|}{$\mathrm{Na}^{+}$} & \multicolumn{2}{|c|}{$\mathrm{Ca}^{+2}+\mathrm{Mg}^{+2}$} & \multicolumn{2}{|c|}{$\mathrm{CO}_{3}^{-2}$} & \multicolumn{2}{|c|}{$\mathrm{HCO}_{3}{ }^{-}$} \\
\hline & & Initial & Final & Initial & Final & Initial & Final & Initial & Final \\
\hline 1 & RSB & 37.5 & 16.95 & 8.2 & 5.55 & 2.4 & 1.1 & 6.8 & 8.5 \\
\hline 2 & RHA & 37.5 & 15.82 & 8.2 & 6.41 & 2.4 & 0.7 & 6.8 & 6.8 \\
\hline 3 & $\mathrm{CP}$ & 37.5 & 20.92 & 8.2 & 6.81 & 2.4 & 1.0 & 6.8 & 7.5 \\
\hline 4 & $\mathrm{AC}$ & 37.5 & 22.54 & 8.2 & 5.71 & 2.4 & 1.6 & 6.8 & 12.5 \\
\hline 5 & $\mathrm{RSB}+\mathrm{CP}$ & 37.5 & 29.70 & 8.2 & 7.8 & 2.4 & 1.6 & 6.8 & 10.8 \\
\hline 6 & $\mathrm{RHA}+\mathrm{CP}$ & 37.5 & 29.70 & 8.2 & 7.9 & 2.4 & 1.2 & 6.8 & 8.2 \\
\hline 7 & $\mathrm{AC}+\mathrm{CP}$ & 37.5 & 24.35 & 8.2 & 7.4 & 2.4 & 1.2 & 6.8 & 10.0 \\
\hline 8 & $\mathrm{AC}+\mathrm{RHA}$ & 37.5 & 30.11 & 8.2 & 6.6 & 2.4 & 1.6 & 6.8 & 9.2 \\
\hline 9 & RSB + RHA & 37.5 & 29.18 & 8.2 & 4.0 & 2.4 & 1.6 & 6.8 & 10.8 \\
\hline 10 & $\mathrm{RSB}+\mathrm{AC}$ & 37.5 & 30.56 & 8.2 & 5.6 & 2.4 & 1.6 & 6.8 & 7.2 \\
\hline 11 & $\mathrm{CP}+\mathrm{AC}+\mathrm{RSB}$ & 37.5 & 24.76 & 8.2 & 5.46 & 2.4 & 0.8 & 6.8 & 10.2 \\
\hline 12 & $\mathrm{RHA}+\mathrm{RSB}+\mathrm{CP}$ & 37.5 & 20.98 & 8.2 & 6.93 & 2.4 & 2.4 & 6.8 & 8.4 \\
\hline 13 & $\mathrm{AC}+\mathrm{RHA}+\mathrm{CP}$ & 37.5 & 23.04 & 8.2 & 5.04 & 2.4 & 3.2 & 6.8 & 8.4 \\
\hline 14 & $\mathrm{AC}+\mathrm{RHA}+\mathrm{RSB}$ & 37.5 & 28.89 & 8.2 & 7.35 & 2.4 & 0.8 & 6.8 & 4.0 \\
\hline 15 & $\begin{array}{l}\mathrm{CP}+\mathrm{AC}+\mathrm{RSB}+ \\
\mathrm{RHA}\end{array}$ & 37.5 & 30.6 & 8.2 & 6.72 & 2.4 & 2.0 & 6.8 & 8.8 \\
\hline
\end{tabular}

Table.6 SAR and RSC of aquifer saline water after adsorption by single and combined adsorbent

\begin{tabular}{|c|c|c|c|c|c|}
\hline \multirow{3}{*}{$\begin{array}{c}\text { S. } \\
\text { No. }\end{array}$} & \multirow{3}{*}{ Adsorbent } & \multicolumn{4}{|c|}{ Parameter } \\
\hline & & \multicolumn{2}{|c|}{ SAR (Initial 18.75) } & \multicolumn{2}{|c|}{ RSC (Initial $1.2 \mathrm{me} / \mathrm{l}$ ) } \\
\hline & & Final & Reduction \% & Final & Reduction \% \\
\hline 1 & RSB & 10.18 & 45.71 & 4.05 & -237.50 \\
\hline 2 & RHA & 8.84 & 52.85 & 1.09 & 9.17 \\
\hline 3 & $\mathrm{CP}$ & 11.34 & 39.52 & 1.69 & -40.83 \\
\hline 4 & $\mathrm{AC}$ & 13.34 & 28.85 & 8.39 & -599.17 \\
\hline 5 & $\mathrm{RSB}+\mathrm{CP}$ & 15.04 & 19.79 & 4.6 & -283.33 \\
\hline 6 & $\mathrm{RHA}+\mathrm{CP}$ & 16.94 & 9.65 & 1.5 & -25.00 \\
\hline 7 & $\mathrm{AC}+\mathrm{CP}$ & 12.66 & 32.48 & 3.8 & -216.67 \\
\hline 8 & $\mathrm{AC}+\mathrm{RHA}$ & 16.58 & 11.57 & 4.2 & -250.00 \\
\hline 9 & RSB + RHA & 17.44 & 6.99 & 6.8 & -466.67 \\
\hline 10 & $\mathrm{RSB}+\mathrm{AC}$ & 18.26 & 2.61 & 3.2 & -166.67 \\
\hline 11 & $\mathrm{CP}+\mathrm{AC}+\mathrm{RSB}$ & 14.99 & 20.05 & 5.54 & -361.67 \\
\hline 12 & $\mathrm{RHA}+\mathrm{RSB}+\mathrm{CP}$ & 11.27 & 39.89 & 3.87 & -222.5 \\
\hline 13 & $\mathrm{AC}+\mathrm{RHA}+\mathrm{CP}$ & 14.51 & 22.61 & 6.56 & -446.67 \\
\hline 14 & $\mathrm{AC}+\mathrm{RHA}+\mathrm{RSB}$ & 15.07 & 19.63 & 4.2 & -250.00 \\
\hline 15 & $\mathrm{CP}+\mathrm{AC}+\mathrm{RSB}+\mathrm{RHA}$ & 16.70 & 10.93 & 4.08 & -240.00 \\
\hline
\end{tabular}


Fig.1 View of different adsorbents

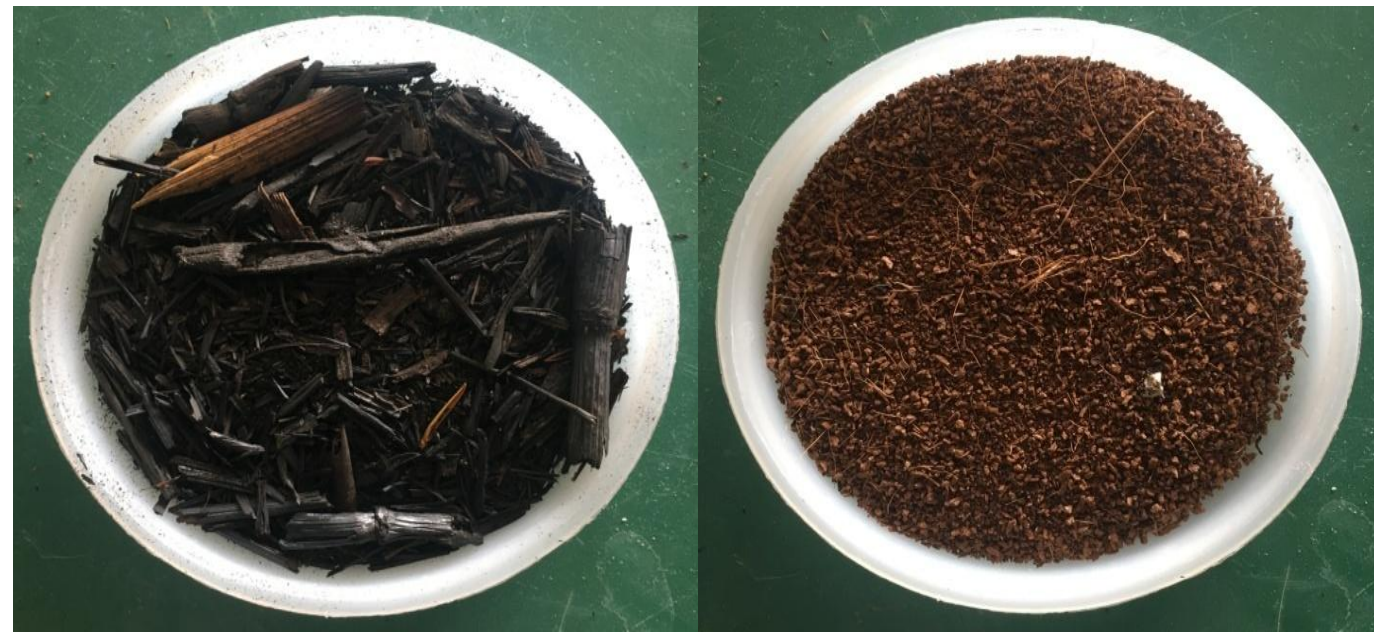

(a) Rice straw biochar (RSB)

(b) Coco peat (CP)

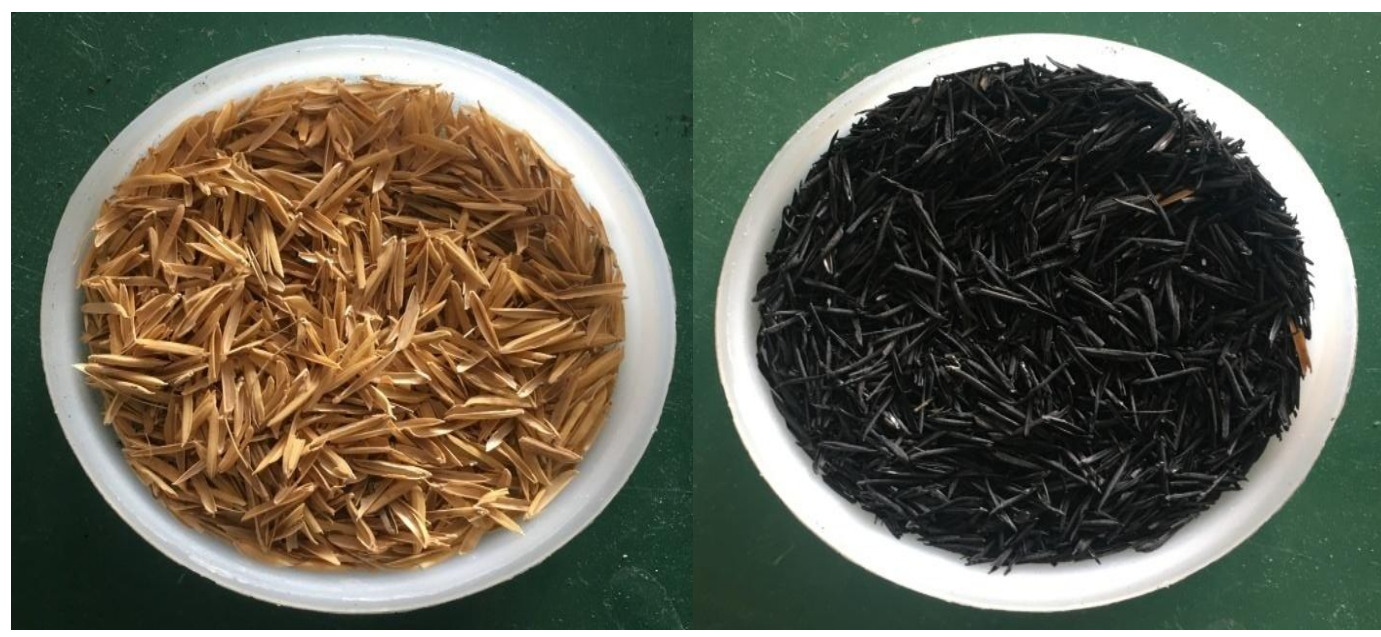

(c) Rice husk (RH)

(d) Rice husk ash (RHA)

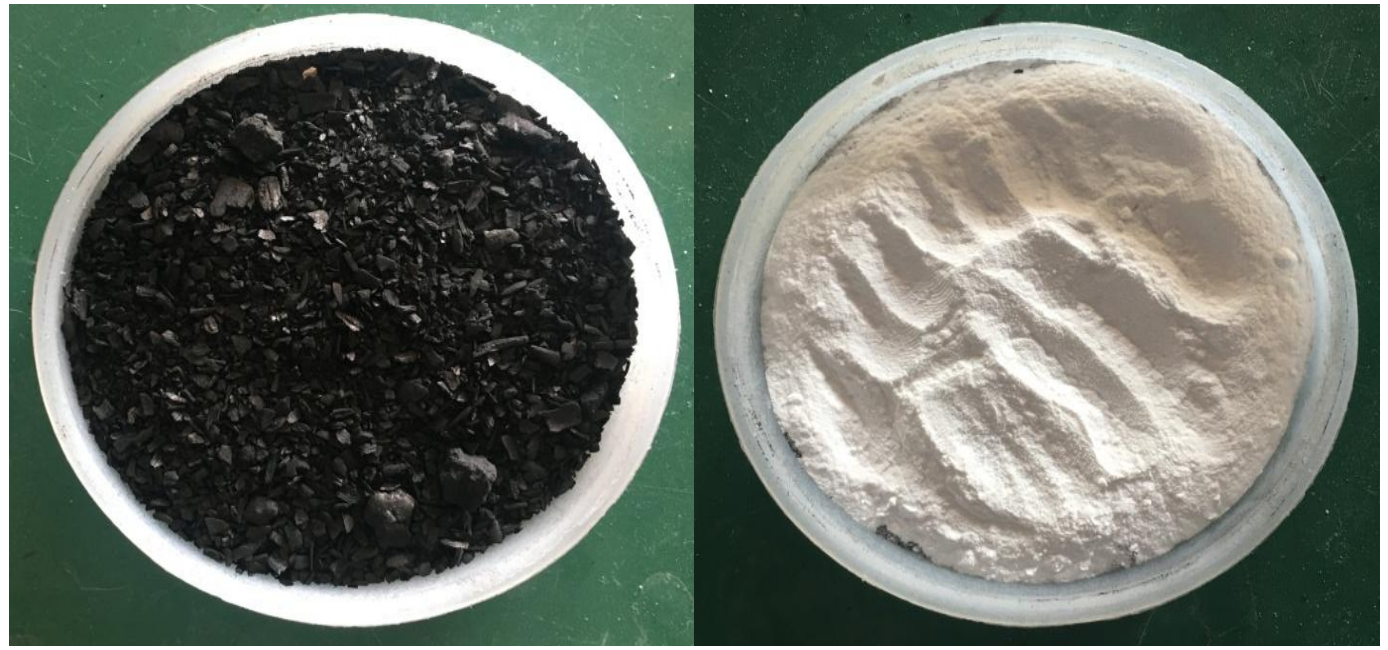

(e) Activated charcoal (AC)

(f) Zeolite (ZL) 
Fig.2 Experimental setup to determine optimum contact time

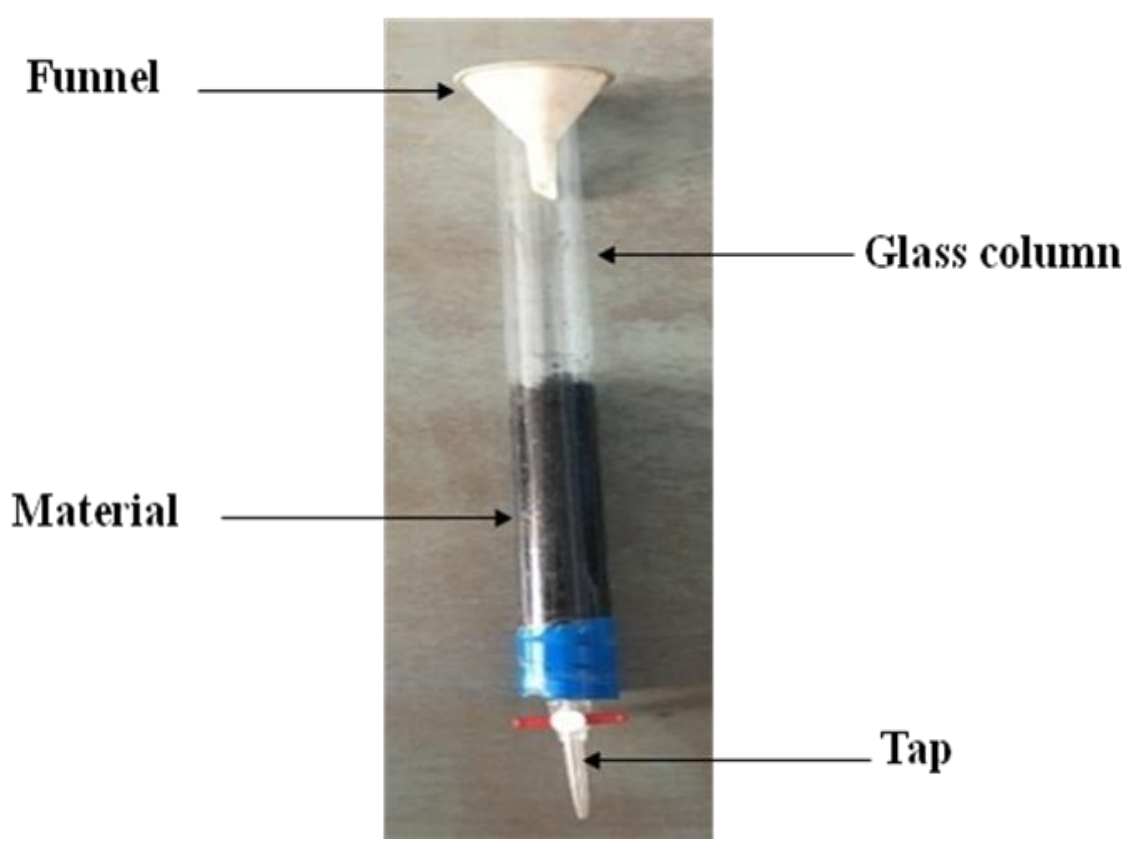

Fig.3 Experimental setup for batch adsorption

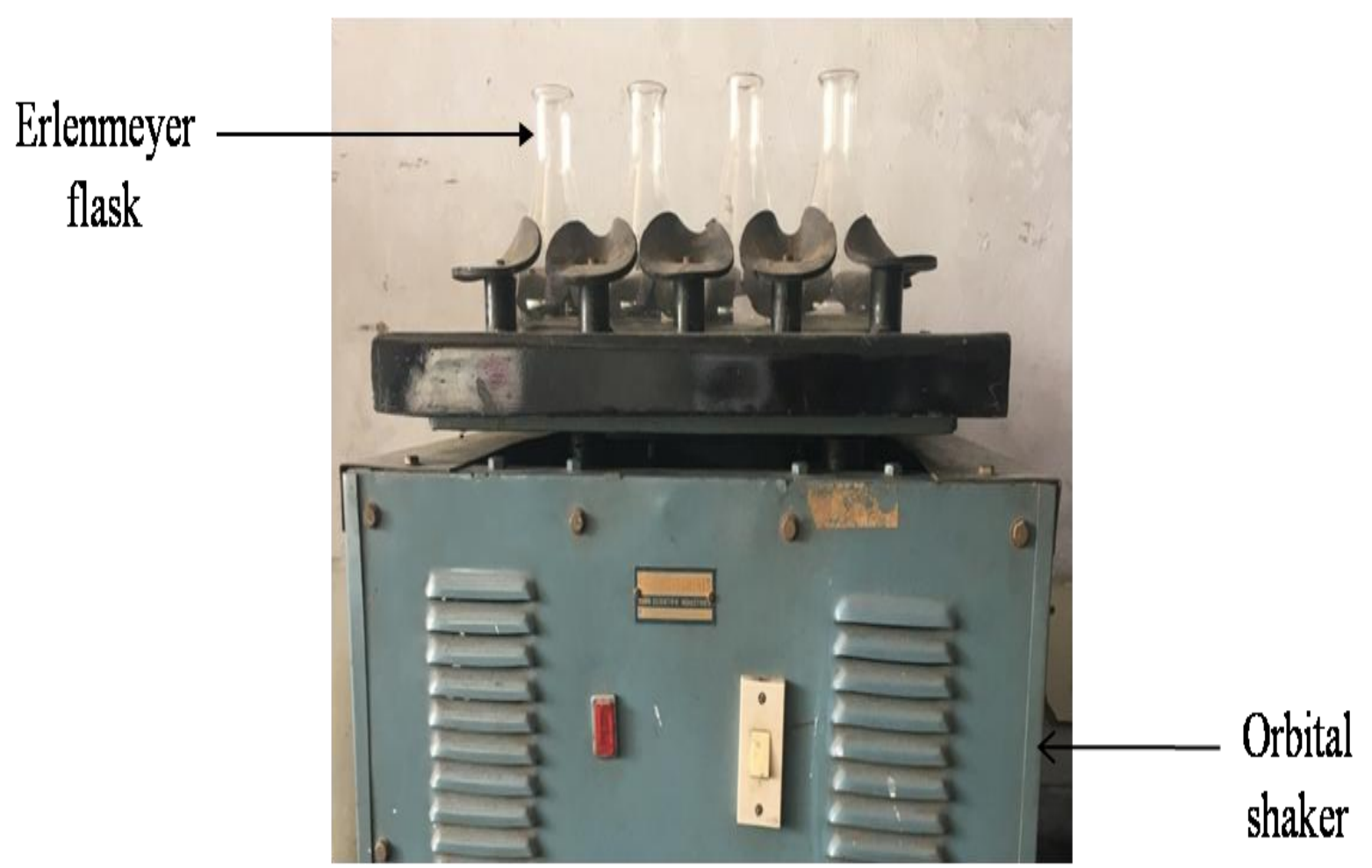


Fig.4 Percentage of $\mathrm{Na}^{+}$adsorption by adsorbents using batch and column method

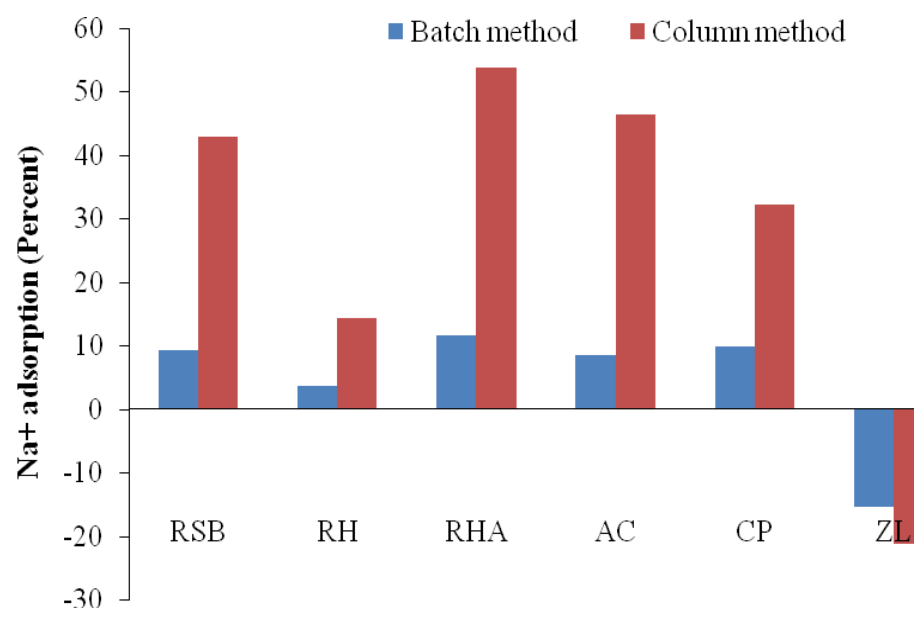

Fig.5 Adsorption of $\mathrm{Na}^{+}$by adsorbents using column method at different contact time

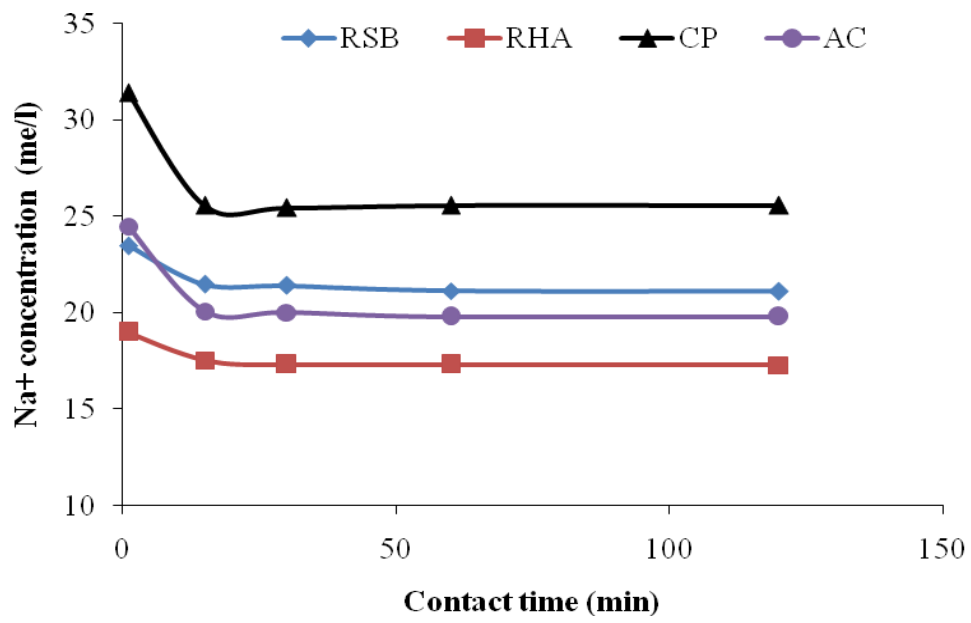

Fig.6 Adsorption of $\mathrm{NaCl}$ from simulated saline water at optimum contact time

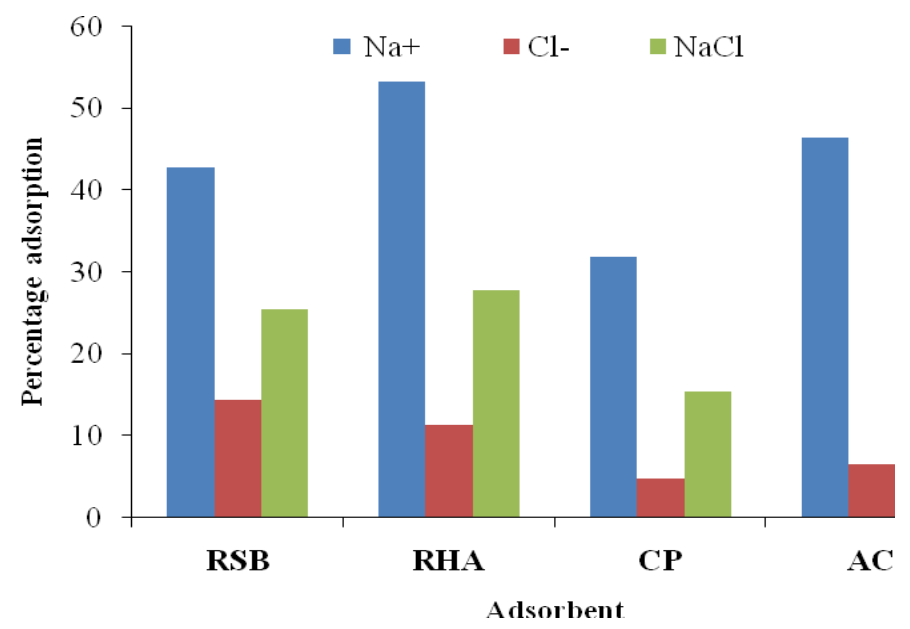




\section{Determination of optimum contact time for} adsorption

All selected adsorbents were further studied to determine optimum contact time for adsorption. For this, adsorption of $\mathrm{Na}+$ by four adsorbent from saline water were carried out using column method at contact time for $1,15,30,60,120$ minutes. Treated water was filtered through Whatman filter paper and was tested for $\mathrm{Na}+$ concentration present in each sample. From figure 5, it was clear that after 15 minutes there was instant decrease in adsorption rate for all the adsorbents. So, there was no need to go for adsorption for contact time beyond $15 \mathrm{~min}$ and this contact time was selected as optimum contact time for adsorption.

\section{Adsorption of sodium chloride ( $\mathrm{NaCl}$ ) salt at optimum contact time}

Sodium chloride $(\mathrm{NaCl})$ salt adsorption was carried out for contact time of 15 minutes using column method by four adsorbents. Resulted water from column was filtrated through Whatman filter paper and was tested for $\mathrm{NaCl}$ concentration present in sample. Investigation of figure 6 shows $\mathrm{NaCl}$ adsorption capacity of adsorbents is in order: Rice husk ash > Rice husk biochar > Activated charcoal $>$ Coco peat.

Single and combination studies of adsorbents using aquifer saline water

In these studies, single and all possible combination of selected four adsorbents were used to carry out the adsorption. Double, triple and quadruped combination of four adsorbents was prepared. In every combination, volume proportion of mixed adsorbents was kept same. Adsorption was carried out using column method at optimum contact time i.e. $15 \mathrm{~min}$. After treatment resulted water from glass column was filtrated through Whatman filter paper and was tested for ion concentration present in treated water. Results are shown in table 5. From above determined ion concentration of treated water, water quality parameter SAR and RSC were determined and presented in table 6 .

After analyzing results of single and combination adsorbent studies, RHA was found out to be the best adsorbent material because of its capacity to decrease SAR value of simulated saline water was more than any others materials and its RSC result was better than any other material.

In conclusion, column method was found to be a better adsorption technique than batch method to achieve desalination as its $\mathrm{Na}+$ adsorption capacity was more.

Optimum contact time for all adsorbents was found out to be 15 minutes.

Rice husk ash has higher percentage of sodium chloride adsorption of $27.83 \%$, followed by rice straw biochar $(25.52 \%)$, activated charcoal $(22.21 \%)$ and coco peat $(15.46 \%)$.

RHA was found out to be the best adsorbent which reduced sodium adsorption ratio from 18.75 to 8.84 below permissible limit (18).

\section{Acknowledgement}

We are extremely thankful to the Indian Council of Agricultural Research (ICAR); New Delhi for funding the work through the scheme, "All India Coordinated Research Project on Plasticulture Engineering and Technology".

\section{References}

Al-Hamaiedeh H. and Bino M., 2010. Effect of treated grey water reuse in irrigation on soil and plants. Desalination, 256(1):115119. 
Abedi-Koupaia J. and Mohri-Esfahania E., 2012. Desalination of water using nanoparticles of husk ashes in sand filter. Proc 4th International Conference on Nanostructures. Pp. 1150-1152. Sharif University of Technology, Kish Island, Iran.

Ahmaruzzaman M. and Gupta V. K., 2011. Rice husk and its ash as low -cost adsorbents in water and wastewater treatment. Ind. Eng. Chem. Res. 50:13589-613.

Apreutesei R. E., Catrinescu C. and Teodosiu C. 2008. Surfactant-modified natural zeolites for environmental applications in water purification. Environ. Eng. Manage..J., 7:149-61.

Crombie K., Mašek O., Sohi S. P., Brownsort P. and Cross A., 2013. The effect of pyrolysis conditions on biochar stability as determined by three methods. GCB Bioenergy, 5: 122-131.

Ganjegunte G. K., Vance G. F., Gregory R. W., Urynowicz M. A. and Surdam R. C., 2011. Improving saline-sodic coalbed natural gas water quality using natural zeolites. J. Environ. Qual., 40: 57-66.

Jha G., 2016. A review on drip irrigation using saline irrigation water in potato (Solanum tuberosum L.). J. Agroecol. And Natur. Resour. Manag, 3:43-46

Minhas P. S., 1996. Saline water management for irrigation in India. Agric. Water Manage, 30: 1-24.

Nangare D. D., Singh K. G. and Kumar S., 2013. Effect of blending fresh-saline water and discharge rate of drip on plant yield, water use efficiency (WUE) and quality of tomato in semi-arid environment. Afr. J. Agric. Res. 8: 363945.
Rodell M., Velicogna I. and Famiglietti J. S., 2009. Satelliye-based estimates of groundwater depletion in India. Nature, 460 (7258): 999-1002.

Scaglioni P. T. and Badiale-Furlong E., 2016. Rice husk as an adsorbent: A new analytical approach to determine aflatoxins in milk. Talanta, 152:423-31.

Shakeri A., Hazeri N., Valizadeh J., Hashemi E. and Motavalizadeh Kakhky A. R., 2012. Removal of lead (II) from aqueous solution using cocopeat: An Investigation on the Isotherm and Kinetic. Iran $\mathrm{J}$. Chem. Eng., 31:45-50.

Singh M., Poonia S. R. and Pal R., 1986. Improvement of irrigation water by gypsum beds. Agric. Water Manage, 11: 293-301.

Singh R.B., Minhas P.S., Chauhan C.P. and Gupta R. K., 1992. Effect of high salinity and SAR waters on salinization, sodication and yields of pearl-millet and wheat. Agric. Water Manage, 21(1-2): 93105.

Suarez D.L., Wood J. D. and Lesch S. M., 2006. Effect of SAR on water infiltration under a sequential rain-irrigation management system. Agric. Water Manage, 86(1):150164.

Sudaryanto Y., Hartono S. B., Irawaty W., Hindarso H. and Ismadji S., 2006. High surface area activated carbon prepared from cassava peel by chemical activation. Bioresour. Technol. 97: 734-739.

Wang S., Terdkiatburana T. and Tadé M. O., 2008. Adsorption of $\mathrm{Cu}$ (II), $\mathrm{Pb}$ (II) and humic acid on natural zeolite tuff in single and binary systems. Sep. Purif. Technol. 62: 64-70.

\section{How to cite this article:}

Parminder Singh, Sunil Garg, Sanjay Satpute and Angrej Singh. 2017. Use of Rice Husk Ash to Lower the Sodium Adsorption Ratio of Saline Water. Int.J.Curr.Microbiol.App.Sci. 6(6): 448-458. doi: https://doi.org/10.20546/ijcmas.2017.606.052 